\title{
Dag Husebø
}

Ph. D. kandidat ved Det humanistiske fakultet,

Universitetet i Stavanger

\section{Pedagogisk tilnærming og fagkunnskap i samspill - En klasseromsstudie av undervisning i faget Religion, livssyn og etikk}

\section{Sammendrag}

Artikkelen analyserer tros- og livssynsundervisning gjennomført i larerutdanningens obligatoriske praksisopplering ved Universitetet i Stavanger (UiS) 2008-2009. Undervisningen inngikk i det ordinæere valgemnet Religion, livssyn og etikk (RLE), og var samtidig integrert i FoU-prosjektet Religionsundervisning og mangfold (ROM). Målsetningen i ROM var å prøve ut en bestemt religionspedagogikk med tanke på håndtering av religiøst mangfold i skole og lcrerutdanning. I lcererutdanningsdelen av prosjektet etablerte fem lcererstudenter, to praksislcerere og to faglcerere et praksisfellesskap som arbeidet individuelt og kollektivt $i$ lys av aksjonsforskningsprisipper. Hver deltaker utviklet sitt didaktiske utprøvingsprosjekt med forankring i den valgte teorien, støttet av praksisfellesskapet. Praksisfellesskapets samhandling ble bl.a. dokumentert gjennom bruk av audio- og videoopptak. Spørsmålet som stilles er på hvilken måte den pedagogiske teorien som ble prøvd ut avdekket behov for bestemt fagkunnskap i undervisningen, og hvordan elevene responderte på denne RLE-undervisningen. Funn i videomaterialet som indikerer at valg av religionspedagogisk teori påvirket behovet for bestemt fagkunnskap i undervisningen, analyseres ncermere.

\section{Innledning}

Spørsmål om hvordan man kan leve sammen i et flerreligiøst samfunn med evne til dialog på tvers av tros- og livssynsgrenser, er aktualisert de siste årene i politisk og mediebasert debatt. Det blir pekt på hvordan verdenssamfunnet blir utfordret av et økende tros- og livssynsmangfold, og man framhever betydningen av dialog og toleranse. (OSCE, 2007). At slike utfordringer tas på alvor, kommer blant annet til uttrykk gjennom forsøk på å endre samfunnsinstitusjoner. I Norge ble en offentlig utredning igangsatt av Kunnskapsdepartementet i 2006 for å endre formålsparagraf for barnehage og opplæring. Utviklingstrekk som ble lagt til grunn var endringer i det norske samfunnet siden 1970-årene. "På mange måter er økt pluralisme et stikkord. Demografiske endringer har ført til større kulturelt, religiøst og etnisk mangfold. Det norske 
"vi” er blitt større og mindre homogent." (NOU, 2007:6, s. 16). Den nye formålsparagrafen fremhever at skolen skal bygge på verdier som "menneskeverdet og naturen, på åndsfridom, nestekjærleik, tilgjeving, likeverd og solidaritet, [...]'”(§ 1-1, Opplæringsloven, 2008). Innsikt i kulturelt mangfold og respekt for den enkeltes overbevisning, er danningsoppgaver som tilskrives faget Religion, livssyn og etikk (RLE). Fagets plassering og funksjon i skole og utdanning forankres i spørsmål om toleranse, dialog og demokratiforståelse. I formål for faget heter det at kunnskap om religioner og livssyn er vesentlig ettersom barn og unge i dag "møter et mangfold av kulturpåvirkninger og verditradisjoner." (K08, s. 31).

Få klasseromsstudier er gjort av RLE-undervisning i skole og utdanning, og vi vet lite om i hvilken grad målene for faget er ivaretatt. Når det gjelder empiriske studier i grunnskole, er et unntak Lied (2004) som har studert elevytringer i form av tegninger, multimodale uttrykk og skriftlige verbaltekster. Hennes studier viser hvordan elever bruker fortellinger fra ulike religioner og livssyn som de møter i faget i sitt identitetsarbeid og sin livstolkning. Et annet studium er gjort av Von der Lippe (2010) som har gjort en diskursanalyse av klasseromsdialoger i ungdomsskolen. Når det gjelder forskning i lærerutdanningens RLE-undervisning, har Flornes (2007) studert effekten av selvorganisert læring og læringssamtaler på studenters læring. Ingen kjente klasseromsstudier er så langt gjort av lærerstudenters RLE-undervisning i praksisopplæring.

FOU-prosjektet Religionsundervisning og mangfold - Tilpasning og utvikling av en fortolkende og kulturbevisst religionspedagogikk (ROM) hadde som hensikt å prøve ut en fortolkende kulturbevisst tilnærming i norsk utdanningskontekst. ROM-prosjektet var finansiert av forskningsrådets program PRAKSISFOU 2005-2010, med mål om å gi ny kunnskap om håndtering av tros- og livssynsmessig mangfold i lærerutdanning og skole. Artikkelen knyttes til utprøving av teorien i norsk lærerutdanning. To praksislærere, fem studenter og to faglærere i RLE ved UiS deltok i denne delen av ROM. Med støtte i aksjonsforskningsprinsipper (Carr \& Kemmis, 1986; Elliot, 1991) ble sykliske utprøvinger og tilpasninger av den religionspedagogiske tilnærmingen gjort av et etablert praksisfellesskap med disse ni som medlemmer (Wenger, 1998). Alle var aktive aktører i både forsknings- og undervisningssammenheng.

Hver enkelt deltaker i praksisfellesskapet utviklet et didaktisk prosjekt med utgangspunkt i egne religionsfaglige interesser. Lærerstudentene som deltok var i deres 3. eller 4. studieår, knyttet til det valgbare fordypningsemnet RLE (60SP) ved Universitetet i Stavanger, 2008-2009. Praksislærerne arbeidet på en lokal praksisskole og hadde ansvar for praksisopplæringen i ROM, mens faglærerne underviste i fagdidaktikkdelen av RLE-studiet på universitetscampus. Både faglærerne og praksislærerne utforsket også den religionspedagogiske teorien i sin praksis som lærerutdannere. Selv om ansvaret for utarbeidelsen av de didaktiske prosjektene lå på hver enkelt deltaker, møttes alle ni til seminarundervisning hvor vi diskuterte våre siste aksjoner. Når vi møttes, preget Wengers teori om 
praksisfellesskap vår praksis og vi var eksplisitte på å utvikle felles målsetninger, forpliktelser og et gryende felles repertoar (Ibid). Når det gjelder studentenes didaktiske prosjekter, ble de først ferdigstilt som skriftlige innleveringer (høst 2008) og operasjonalisert i obligatorisk praksisopplæring (vår 2009).

Hovedlinjene i den teoretiske tilnærming som ble prøvd ut, er at mangfoldet som finnes i klasserom og lokale skolekretser ikke synliggjøres tilstrekkelig ved å undervise om religioner og livssyn kun fra et tradisjonsnivå. Undervisning som bare beskriver religioner og livssyn på et overordnet nivå, vil kunne bli lite nyansert og overse tros- og livssynspluralitet innenfor hver enkelt tradisjon. En fortolkende kulturbevisst tilnærming oppløser ikke tanken om tradisjonenes eksistens, eller ignorerer undervisning om kjennetegn ved disse. Målet er å få til en veksling i undervisningen mellom dette nivået og forhold knyttet til den lokale kontekst hvor undervisningen utspiller seg. Undervisningen må knyttes an til elevenes egne forståelser og livsverden, og aller helst starte i deres egne interesseområder og forforståelser. For å kunne starte undervisningen i elevenes verden må lærer vise sensitivitet overfor enkelteleven og den sammenhengen eleven lever i (Jackson, 1997; Skeie, 1998). Med henvisning til Geertz (1973) tenkes det at undervisningen må planlegges, gjennomføres og vurderes i forhold til "thick descriptions" og etnografiske undersøkelser av den kontekst undervisningen foregår i. Dette vil kunne gi kunnskapen en mer dynamisk karakter, og gjøre at undervisningen kommer nærmere elevenes fortolkninger og interesser (Jackson, 2009; Skeie, 2010).

Det var særlig kjernebegreper utviklet av professor Robert Jackson som ble gjort til gjenstand for utprøving. De didaktiske utviklingsprosjektene var forankret i disse begrepene, og meningsinnholdet i begrepene ble fors $ø$ kt utfordret og utvidet. Begrepet representasjon peker på den måten tros- og livssynstradisjoner blir viet oppmerksomhet generelt og hvordan tradisjonene blir beskrevet spesielt ved hjelp av ulike redskaper. Begrepet refleksivitet peker på sin side på de møter som foregår mellom individuelle forståelser i elevgruppen, og mellom enkeltelevenes tros- og livssynsmessige oppfattelser og lærestoffet. Tanken er at det i tros- og livssynsundervisning forekommer møter mellom ulike forståelser som gjensidig påvirker hverandre. Til slutt legger tilnærmingen vekt på den fortolkning som oppstår i slike møter og den edifikasjon (nyforståelser i vid forstand) elevene vil kunne utvikle gjennom refleksiviteten og fortolkningen. Fortolkningene og nyforståelsen skal imidlertid ikke styres i en gitt retning. (Jackson, 1997, 2004).

Forskningsspørsmålet som stilles i artikkelen er på hvilken måte den religionspedagogiske tilnærmingen som ble prøvd ut avdekket behov for bestemt religionsfaglig kunnskap i undervisningen, og hvordan elevene responderte på RLE-undervisning forankret $\mathrm{i}$ en fortolkende kulturbevisst tilnærming. For å svare på spørsmålet analyseres og diskuteres utdrag fra tre av studentenes didaktiske undervisningsopplegg. 


\section{Metode}

RLE-undervisningen som analyseres ble gjennomført i to syvendeklasser, hvor den første gjennomføringen ble observert, dokumentert og reflektert over av praksisfellesskapet, og deretter forsøkt utbedret i en ny gjennomføring. (Lewin, 1946; Kolb, 1984). Når slik pedagogisk praksis skal studeres, er en feltmetodisk tilnærming naturlig, sier Fuglestad (2007). Skal en studere pedagogisk praksis kvalitativt, må en ikke bare velge seg ut et bestemt felt å studere det i, men en må også delta der praksisen utspiller seg. En inngår som forsker i refleksiv samhandling. "Praksissituasjoner er samhandlingssituasjonar, og den metoden som eignar seg best til å framskaffa data om samhandling, er deltakande observasjon. Som forskar set ein det prosessuelle, samhandlinga, mellom aktørar i fokus.” (Ibid, s.22). Fossåskaret (1997) sier at i kvalitativt orientert tradisjon der en er opptatt av det prosessuelle og relasjonelle, må handling forstås som samhandling om den i det hele tatt skal kunne forstås.

Alvesson \& Sköldberg (2009) påpeker at i refleksiv kvalitativ forskning anerkjennes forskeren som aktivt til stede i forskningsprosessen og i genereringen av kunnskap, mens Hammersley og Atkinson (1996) beskriver de refleksive vilkår for empirisk feltforskning og sier: "Det er viktig å forstå at forskning er en aktiv prosess, hvor man beskriver verden gjennom selektiv observasjon og teoretisk tolkning av det som observeres, ved å stille bestemte spørsmål og deretter tolke svarene, ved å ta feltnotater og skrive av lyd- og bildeopptak, i tillegg til å skrive forskningsrapporter.” (Ibid, s. 48f).

Pedagogiske praksissituasjoner kan en produsere data fra på ulike måter (Aase og Fossåskaret, 2007). Til grunn for min artikkel ligger analyse av videoopptak fra RLE-undervisning. Elevenes foresatte fikk utlevert samtykkeskjema der de bekreftet om de ville la barna sine filme eller ikke. Ca. 20\% ønsket ikke at deres barn skulle delta i opptakene, eller leverte ikke skjemaet tilbake. Klasserommet ble derfor ryddet slik at $3-5$ elever falt utenfor kameravinkelen. Gjennomsnittlig figurerer 11 - 14 elever i opptakene. Videoopptakene strekker seg over 12 RLE-timer. Praksisfellesskapets etterarbeidsmøter i forlengelsen av timene ble også dokumentert med ca. 6 timer filmopptak.

Det er klart at et klasserom med flere voksne observatører og et påskrudd kamera preger undervisningssituasjonen. På eksakt hvilken måte er imidlertid ikke godt å si. En av praksislærerne sier det slik: "Jeg vil mene at elevene oppførte seg stort sett som de pleier. Noen er litt trege og tilbaketrukne, mens andre alltid er veldig til stede.” (Etterarbeidsmøte, 05.02.09). Videodataene må ses som frembrakt i en sosial situasjon preget av samhandling. I mine videoopptak figurerer studenter, elever, praksislærere og faglærere i en felles religionsfaglig undervisningskontekst der videomaterialet er et produkt av våre refleksive samhandlinger. Kvalitativt forskningsmateriale fremkommer alltid i slike refleksive sammenhenger og er kontekstavhengig, sier Alvesson \& Skjöldberg (2009, s. 8). Knyttet til en slik forståelse argumenterer Von der Lippe (2010) for 
en hermeneutisk tilnærming til etnografisk materiale samlet inn gjennom videoopptak. Hennes forskning støtter seg til Raab \& Tänzler (2009) som omtaler sine videoanalyser som videohermeneutikk med fokus på nøkkelscener og hendelser som velges ut på grunn av deres unike og samtidig representative karakter.

I videohermeneutikken forholder man seg til nøkkelscenene med en målsetning om å frembringe "non-reductive and extensive interpretation of the data in all recognizable details and aspects." (Ibid, s.87). Innenfor videohermeneutikken knyttes den fortolkende virksomheten til det empiriske videomateriale forstått som tekst. Denne teksten forstås ikke som en naturlig representasjon av virkeligheten, som avbildet virkelighet, men som tolket allerede fra innsamlingen av. Utvalget av de sekvenser som filmes, kameraets bevegelser og den zooming som foregår, er resultat av tolkninger av det som foregår og må ses som en del av analysen som gjøres (Munthe, 2006).

Videohermeneutikken sees ikke som annerledes enn annen hermeneutisk tolkning her i artikkelen. Eksisterende dokumentasjonskrav i vitenskapelig forskning gjør at alle data kan ses som tekster, sier Fuglseth (2006). Når en transkriberer en dialog eller en observasjon, objektiveres denne som tekst, sier han. Innenfor hermeneutisk tenkning hvor den hermeneutiske spiral står sentralt, vil enhver leser alltid bære med seg forforståelser og spørsmål til en tekst som påvirker de svar og den forståelse teksten vil kunne gi. Derfor må den som styrer kamera og senere transkriberer det som observeres, trekke seg selv inn i tolkningsprosessen og være transparent på dette. "Vi må alltid kunne presentere vår eigen hermeneutiske sirkel anten vi forskar på tekstar, samfunn, institusjonar eller enkeltindivid. Ja, ut frå hermeneutisk teori kan vi argumentere for at forskarar har plikt på seg til å studere samanhengen mellom dei svara dei meiner kjeldene gjer, og spørsmåla dei stiller til kjeldene.” (Ibid, s.144)

Tre nøkkelscener er transkribert og gjort til gjenstand for nærmere tolkning og diskusjon. Måten jeg har frembrakt mine hovedkategorier på er at jeg først har analysert gjennomføringen av studentenes didaktiske prosjekter vertikalt (within-case). Det betyr at hver enkelt students undervisning ble analysert på let etter kjennetegn og særtrekk ved denne (Miles \& Huberman, 1994, s. 90). I denne fasen fant jeg at bestemt religionsfaglig kunnskap fremstod som betydningsfull for den samhandlingen som foregikk i klasserommet, enten denne fagkunnskapen var tydelig til stede eller var påfallende fraværende. For å undersøke på hvilken måte bestemt fagkunnskap preget samhandlingen mellom lærerelev og mellom elevene begynte jeg å lete etter mønster på tvers av de tre studentprosjektene (cross-case) (Ibid, s. 172). Her fant jeg først at det var ulike typer religionsfaglig kunnskap som spilte en viktig rolle for samhandlingen i nøkkelscenene, samtidig som jeg så at den fagkunnskapen som var til stede eller var savnet, hele tiden var forbundet til karakteristika ved den pedagogiske tilnærmingen som ble prøvd ut i ROM. 
Religionsfaglig kunnskap var for det første betydningsfull for måten studentene vurderte elevenes faglige bidrag i undervisningen og evnet å inkludere dem i undervisningen. For det andre fant jeg flere eksempler i materialet på fagkunnskaper som ikke bare knyttet seg til lærebøker, men også til kunnskap om lokalmiljø og elevene i klassen. Det siste mønsteret jeg så var at det å delta i samhandlende læringsprosesser i RLE-undervisning krevde faglig forkunnskap, ikke bare hos den som ledet undervisningen, men også hos elevene. Funnet av dette siste mønsteret medførte at jeg gikk et skritt lenger i analysen og så nærmere på ulike betingelser for elevenes deltakelse i undervisningen. Det som avtegnet seg da, var at deres muligheter til faglig forberedelse viste seg som en betydningsfull faktor og likeledes at de oppfattet temaet som relevant. Graden av faglig utfordring som lå til ulike arbeidsoppgaver, viste seg også å gi utslag på elevenes motivasjon for deltakelse.

Tre hovedkategorier er konstruert i tilknytning til nøkkelscenene, og det er disse nøkkelscenene som nå vil analyseres nærmere. Sentrale funn vil bli løftet frem og til slutt diskutert i lys av den evne og vilje elevene viste til å delta faglig i undervisningen:

- Inkluderende vurdering

- Kontekstualisering av fagkunnskap

- Undervisning som samhandling

\section{Inkluderende vurdering}

Kategorien inkluderende vurdering ble analysert frem fra RLE-undervisning med fokus på ritualer. Undervisningen beveget seg mellom religiøse og ikkereligiøse ritualer og mellom kjente ritualer fra elevenes egen livsverden og ukjente ritualer fra andre kulturkontekster. Gjennom å starte i elevenes liv og gi kjent innhold til det abstrakte begrepet ritual, var målet at undervisningen skulle skape forutsetninger for å lære om et ukjent overgangsritual fra en annen kulturkontekst. Nøkkelscenen foregår idet tavla er fylt av mange assosiasjoner til ritualbegrepet i et tankekart. Frem til nå har studenten ryddet elevenes innspill i religiøse og ikke-religiøse ritualer og i ulike faglige kategorier som kalenderritualer og overgangsritualer. Etter 19 minutter ber han elevene skrive om et ritual de kjenner. "Det kan være dåp, bryllup, begravelse, konfirmasjon eller liknende.”, sier studenten. Det er da følgende ytring kommer fra en elev som allerede har bidratt med påske som eksempel på et religiøst ritual: ”Å, jeg vet om et ritual, Id.”

1 Student Hva det er? Det har jeg ikke engang hørt om.

2 Siri Id, har du ikke hørt om Id? Det er en muslimsk feiring.

3 Student Åh ja, ja, ja kjempebra. 
4 Trond $\quad$ Åh, Ramadan.

5 Siri Ja, det visste jeg.

6 Student Ja, dette er kjempegode eksempler på ritualer som foregår i andre religioner.

7 Student Dere skal få utdelt ark av meg nå. Så velger dere ut et ritual som dere skriver litt om, og så skal jeg gi dere noen stikkord som jeg vil at dere skal svare på. Eller noen spørsmål som jeg vil dere skal svare på i forbindelse med det ritualet som dere skal skrive om (Skriver dem opp på tavla).

8 Student Jeg vil altså at dere skal svare på hva som skjer i ritualet, hvem som utfører ritualet, hvor det foregår og hvilken betydning det har for den som utfører det.

(Videoopptak 7A, 03.02.09)

Studenten formulerer pkt. 8 som fire punkter på tavlen, og etter at elevene har arbeidet individuelt med disse spørsmålene i 8 minutter, henvender han seg igjen til klassen. Først gir elevene en beskrivelse av bursdag som ritual og deretter av jul. Så henvender studenten seg til en gutt som er sikh og inviterer ham til å si noe om ritualet han har skrevet om, Holy. Gutten ønsker ikke å bidra med sin fortelling, som han for øvrig ikke har skrevet noe videre om. Når alle elevene inviteres til å bidra på ny, rekker Siri opp en ivrig hånd igjen og leser:

9 Siri Ja, Id er et rituale som man utfører i slutten av Ramadan. Det er festen etter Ramadan. På festen har man masse god mat. Id er et Islamsk riuale. Før Id faster man i en måned i løpet av Ramadan. På kvelden slutter fastingen. De som utfører ritualet er muslimene selv. De minste faster ikke. Ritualet foregår hvor som helst. I hjemmet sitt eller i rettslokaler. Ritualet foregår i Ramadan, og Ramadan betyr faste. Og betydningen av ritualet er at man tenker på fattige.

(Videoopptak 7A, 03.02.09)

Det scenen viser (pkt. 1 og 3), er hvordan en religionslærers manglende fagkunnskaper kan medføre at gode innspill fra elevene ikke gis den plass de fortjener i undervisningssituasjonen. Selv om studenten kjenner til Id som rituale, og først og fremst ikke oppfatter det eleven sier, bekreftes det senere at mer kunnskap ville gjort at han nok hadde viet mer tid på ritualet når det ble spilt inn (Etterarbeidsmøte, 05.02.09). Selv om jeg velger å vektlegge tidsaspektet og spørsmål om inkludering i min analyse, er det verdt å kommentere at en lærer som ikke har tilegnet seg så sentral kunnskap om Islam, vil kunne stå i fare for å miste sin faglige legitimitet i klassen.

I pkt. 3 er studenten rosende, men ikke inkluderende på en måte som gir oppmerksomhet til den kunnskapen Siri bringer inn og derigjennom anerkjenner denne kunnskapen som viktig. I tillegg distribueres ikke kunnskapen videre til de andre. Hva Id og Ramadan er, lar han stå ukommentert og unnlater dermed å sikre at begrepene gis faglig innhold. Når nøkkelscenen ses i sammenheng med de andre nøkkelscenene (cross-case), tydeliggjøres det at elevers deltakelse vil kunne bli vurdert ulikt avhengig av hvilken fagkunnskap RLE-læreren besitter. Også de andre studentene i ROM stoppet nemlig opp og viet mer tid og oppmerksomhet på faglige innspill de selv var fortrolige med, enn når de var 
usikre. En kan si at det ble bedrevet både inkluderende og delvis ekskluderende vurderinger av elevenes faglige innspill på bakgrunn av studentenes faglige forkunnskaper.

Nøkkelscenen viser også spor av den religionspedagogikken som ble prøvd ut. Sentrale kjennetegn er at elevene selv får gi innhold til begrepet ritual ut fra egen livskontekst, og at det ryddes i faglige forståelser tilpasset elevenes eget ståsted. Som et forsvar for at det ikke ble gitt en lengre utleggelse av Id fra studenten som ledet undervisningen, påpeker en medstudent at det tross alt var elevene som skulle beskrive et kjent ritual i denne utprøvingen (Etterarbeidsmøte, 05.02.09). Hun argumenterer med at Siri slik fikk anledning til å inkludere seg selv, og at hun i tillegg fikk anerkjennelse fra sine medelever for sin kunnskap. I materialet finnes flere eksempler på elever som høstet positive tilbakemeldinger fra sine medelever på grunn av faglige bidrag i undervisningen (Etterarbeidsmøte, 05.02.09).

Til slutt kan vi ved å studere scenen se at valg av pedagogisk tilnærming var i samspill med og påvirket behovet for bestemt religionsfaglig kunnskap. Scenen kan forstås slik at studenten var mer opptatt av å forberede seg i pedagogisk forstand, enn av å forberede seg på å bære spesifikk fagkunnskap om ritualer inn i timen. Med en annen pedagogisk tilnærming ville studenten kanskje intuitivt ha forberedt seg grundigere på det sistnevnte og fremstått som tryggere faglig sett. Men på samme tid kunne undervisningen hans da ha blitt mer lukket til hans normative utvalg og forståelser.

\section{Kontekstualisert fagkunnskap}

Den neste nøkkelscenen som analyseres, er knyttet til et didaktisk prosjekt hvor en student dro veksler på sin dramapedagogiske kompetanse. Denne studenten ville arbeide med begrepet tilgivelse. Begrepet ble knyttet til Kristendommen som hovedområde i K08, og anskueliggjort med eksempler fra et tradisjonsnivå, et lokalt nivå og fra elevenes egen livsverden. Det første elevene gjorde var dramapedagogiske øvelser knyttet til avvisning og imøtekommenhet. Deretter ble en fortelling om en jente på elevenes alder lest. Fortellingen forankret spørsmål om tilgivelse i en gjenkjennelig familiekontekst. Så ble elevene utfordret til å finne likheter og ulikheter mellom tre ulike artefakter. Et bilde av Tone (hovedpersonen i fortellingen som var lest), et bilde av tidligere biskop Baasland i Stavanger og et eksemplar av Bibelen ble vist fram. Den såkalte "Baaslandsaken” var behørig dekket i både lokale medier og i riksmedia i 2008.

1 Student Nå skal jeg gi dere oppgaven. Hva har disse tre tingene til felles? Dere skal skrive det ned og dere skal tenke selv og skrive det ned individuelt, ikke sant. Dere skal ikke snakke med naboen nå, fordi vi skal snakke om det etterpå. Det er viktig for meg og for dere, å skrive ned det dere kommer på. Det dere mener de har til felles. Tone, biskop Baasland og Bibelen. Hvilke tema har de til felles? Hvilke 
budskap har de til felles? (Stillhet...) Det er ikke farlig om dere finner dette litt vanskelig. Skriv ned det første dere tenker på og bruk litt tid. (Stillhet...)Vi bruker $10 \mathrm{~min}$. Alle forslag er gode forslag. For å hjelpe dere kan dere tenke hva novellen handlet om.

2 Student Skal jeg gi dere noen stikkord til. Synes dere det var vanskelig? Jeg kan gi dere noen stikkord til. Som jeg sa, hva handler denne om (henvendt til bilde av Tone fra fortellingen) og hva vil den fortelle oss. Hvordan møtte han (henvendt til bilde av biskop Baasland) sin gutt når han forstod at han hadde gjort så mye galt? Hva sa han til ham? Hva har han sagt om han i media?

(Videoopptak 7A, 20.01.2009)

Etter at alle elevene har fått jobbet ferdige med skrivearbeidet, fortsetter studenten:

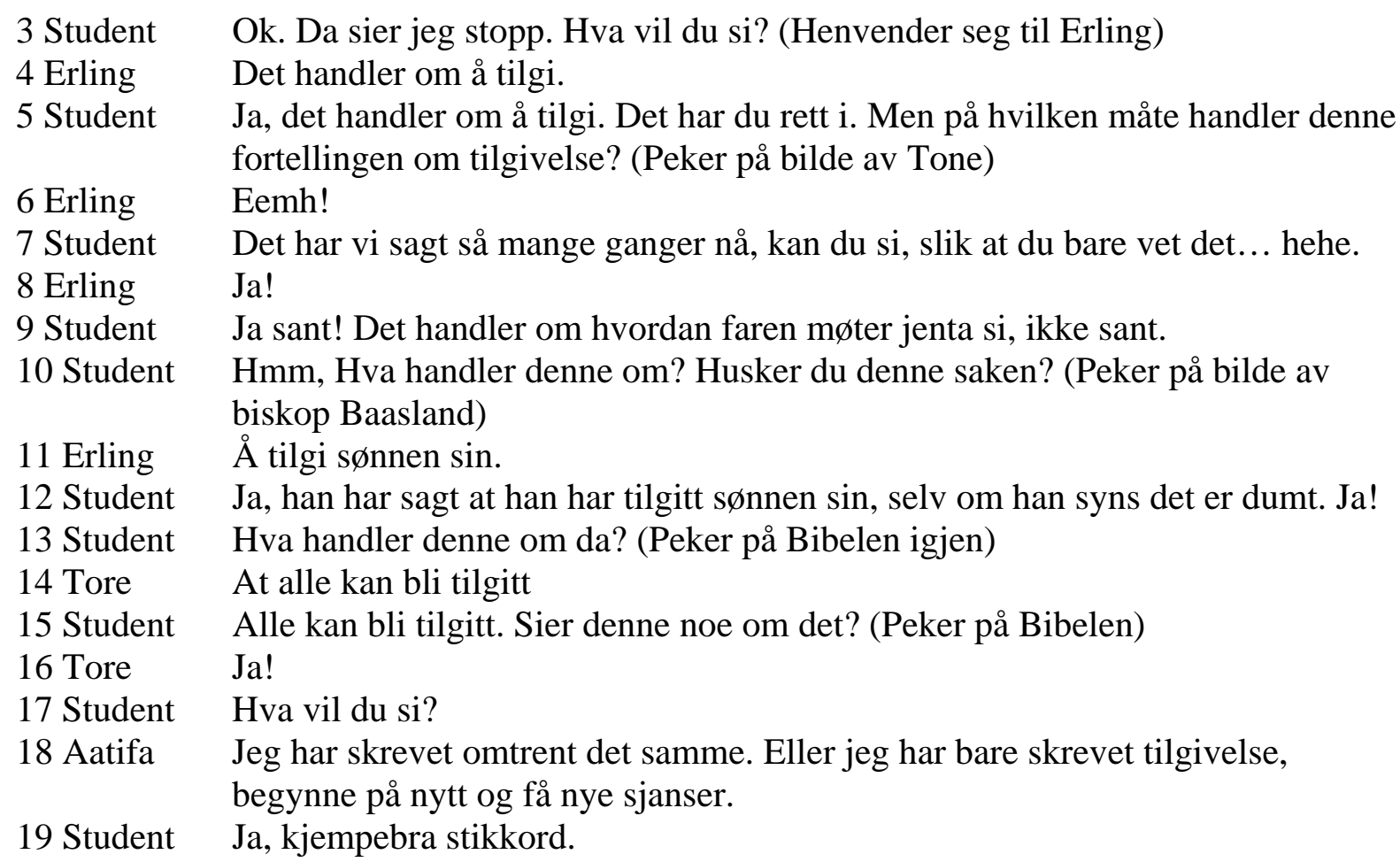

(Videoopptak 20.01.2009)

Etter noen flere tolkninger leses lignelsen om ”Den bortkomne sønn” (Luk. 15, 11-32).

Det som gjør dette til en nøkkelscene, er at den viser hvordan studenten kontekstualiserer tilgivelsesbegrepet på flere nivå. Hun starter med dramaøvelser som gir elevene erfaringer av å bli avvist eller imøtekommet. Deretter pendler (Jackson, 1997) studenten undervisningen i retning av en fortelling og en lokal hendelse som anskueliggjør begrepet i elevenes livsverden og i en lokal kontekst. Ikke før elevene har fått bearbeidet hva tilgivelse vil kunne innebære på disse nivåene, løftes undervisningen i retning begrepets betydning i kristendommen. 
Det å forankre undervisningen i elevenes egen verden og la denne kaste lys på tros- og livssynsmessig tradisjonsstoff, er influert av den religionspedagogiske tilnærmingen som prøves ut. Her forsøker studenten å sikre en representasjon av kristendomsfaglig kunnskap på ulike kontekstuelle nivå. Nøkkelscenen viser at dette krever fagkunnskap som knytter seg til de ulike nivåene. Vi ser en student som har tilegnet seg fagkunnskaper om hva som kan være gyldig og relevant kunnskap for elevene, hva som foregår i et lokalt medieog menighetsbilde og hva som forbinder dette til kjernestoff i kristendommen. Men samtidig viser scenen også en forholdsvis lærerstyrt undervisning hvor elevene ledes i retning av fortolkninger studenten har gjort av kristendommen. Studentens tolkning av begrepet tilgivelse og eksempelet som brukes, kunne med fordel ha vært diskutert og åpnet for alternative tolkninger.

En siste interessant pendling som studenten foretar, er at spørsmål som har med tilgivelse å gjøre, igjen forankres til elevenes egen livsverden. Elevene settes til slutt i gang med å dramatisere en egen fortelling om tilgivelse hvor de selv har hatt behov for tilgivelse eller har fått dette. Her gis elevene den hele og fulle regien. Et interessant funn som avdekkes nå, er at andre elever enn de som tidligere har markert seg, tar styringen. Jeg kommer tilbake til dette funnet i den avsluttende diskusjonen om deltakelse og elevrespons.

\section{Undervisning som samhandling}

Den siste nøkkelscenen eksemplifiserer undervisning som samhandling (Wadel, 2005). Scenen er knyttet til et utviklingsprosjekt som fokuserte på undervisning om hinduisme gjennom et Ganesh-mantra. Arbeidet med mantraet og andre estetiske uttrykk ble forankret i konkrete kompetansemål (K08), og studenten vektla at det lå viktig kunnskap om hinduismen innbakt i mantraet. Etter første gjennomføring overfor 7A, reviderte studenten operasjonaliseringen av studentprosjektet på to viktige punkter. For det første endret hun betingelsene for elevenes mulighet til å tolke mantraet som ble spilt, og for det andre endret hun sine egne betingelser for å lede de fortolkende prosessene.

Introduksjonen av økten var svært kort ved første gjennomgang i 7A. Umiddelbart etter at studenten har presentert seg ved navn, blir elevene fortalt at de skal få høre et musikkeksempel. Elevene blir bedt om å tenke etter hva de hører, finne ut hvem som er utøvere, hvordan musikkstykket blir utført og hvilke musikkinstrumenter som brukes. Deretter skrus mantraet på. Selve avspillingen varer i 2.5 minutt, og uten nærmere innramming, er min tokning at dette virker lenge for elevene. De fremstår som usikre og det er mye latter. Elevenes respons etter avspillingen går i svært ulike retninger og har liten relevans i forhold til spørsmålene de utfordres på i forkant. Elevene mangler tolkningsnøkler som kan knytte mantraet til hinduismen. Det neste som gjøres er at elevene gis en oppgave der halve klassen skal knytte ett ord til mantraet, mens den andre 
halvdelen skal tegne det de assosierer mens mantraet spilles to ganger til. Innspillene fra elevene har igjen få faglige forankringer i de kompetansemål som er valgt ut. "Religion”, "Gud”, "musikk når de ber”, "en indre ro" nevnes. De fleste tegningene er abstrakte, med unntak av noen figurer som sitter i lotus (Videoopptak 7A, 13.01.2009).

Ved neste operasjonalisering, i 7B, forbereder studenten seg på å bruke lengre tid til å innlede timen. Etter å ha presentert seg innleder hun med en lysbildeserie hvor elevene blir fortalt at de skal ut på en reise til India, og det vises mange bilder. Etter at mantraet er spilt her, gis innspill med større faglige forankringer til hinduismen. I 7B fortolker elevene mantraet i lys av hva de allerede vet (Videoopptak 7B, 16.01.2009). Før mantraet spilles for andre gang, gis også en mer komplisert oppgave. Elevene skal knytte flere assosiasjonsord til det de hører, og tegningene skal forankres i deres kunnskap om tradisjonen. Ord som: "Munk", "OM”, "slappe av", "bønn”, "meditasjon” spilles inn, og tegningene som vises frem er av "meditasjon", "røkelse", "personer i lotus stilling" m.m. (Videoopptak 7B, 16.01.2009).

En annen ting som ble gjort annerledes overfor klasse 7B, er at studenten forberedte seg faglig på de mest sannsynlige tolkninger som ville gis av et Ganesh-bilde. Første gang bildet ble vist, var studenten i liten grad forberedt på hva dette ville føre til av innspill og assosiasjoner, og hun ble bokstavelig talt bombardert av elever som syntes at "bildet var rart," at "Ganesh så fet ut”, at her var "mange forskjellige farger" osv. (Videoopptak 7A, 13.01.2009). Innspillene var overfladiske, og det ble vanskelig å lede tolkningsprosessen mot kunnskapsmessig innhold i bildet. Studenten beskriver det slik:

Utfordringen i møte med en slik mengde av innspill er å balansere dem slik at elevene sitter igjen med en form for forståelse for hva som er faglig viktig, og hva som ikke er det. Mye av det elevene kom med var hentet fra populærmusikk og tv-serier, og er på sett og vis relevant i forhold til emnet, men man trenger å trekke linjene fra det allmenne og kulturelle til det religionsspesifikke.

(BA oppgave, 2009, s. 21)

Ved andre gjennomføring har hun større beredskap til å gjøre bruk av de assosiasjoner som gis, og har forberedt seg bedre faglig til å lede fortolkningen. Hun har tilegnet seg mer kunnskap om den betydning og funksjon Ganesh har i kunstneriske fremstillinger. Nøkkelscenen illustrerer dette:

1 Ole $\quad$ Hva er det guden Ganesh står for?

2 Student Han ber de til når noe er vanskelig. Da ber de for hell og lykke. Han er en slags lykkegud, kan en gjerne si. Er det noen som kan tenke seg hvorfor han er det?

3 Trude For han klarte å leve videre selv om han ble kappet hodet av!

4 Student Det kan godt være. Er det noen som kan tenke seg en annen ting også kanskje? 
5 Gro Han fikk lov til å leve igjen. Men det er en annen ting jeg tenkte å si. Eh, jeg er ikke sikker, men blomsten han holder i den bakerste hånden (en lotus) kan være for sånn fred og sånn. Og i den andre bakerste hånden (en fork) og i den fremste (en $ø k s)$ er for at han skal holde vakt. Men der hvor han viser hånden ser det ut som om han har et merke i midten.

6 Student Skal vi ta disse hendene. Skal vi se, da tar vi denne først. Hva holder han i den?

7 Gro En sånn for å holde vakt. Og for å vise hva de brukte for å hogge av hodet, tenkte jeg.

8 Student Ja, øksen som hodet ble hogget av med. Og hva er det merket dere ser inni her

9 Geir Det er en tatovering.

10 Oddvar Det er det der merket som ser ut som et tretall med noe bak der. Det der hindutegnet.

11 Student Ja, kjempebra. Det er OM-tegnet. Etter en stund skal dere få se det når jeg blåser det opp.

12 Student Det var øksen og det var OM-tegnet, og så sa du noe om den blomsten der (henvendt til Gro).

13 Flere Det er et fredstegn.

14 Student Et fredstegn ja, og så kan det også være et symbol på Paravati. Gudinnen som var moren til Ganesh.

15 Student Og så siste har en den her i den fjerde hånden (henvender seg til forken).

16 Gro Det er den til å holde vakt med

17 Student Ja, og så er det samtidig et symbol på Shiva

(Videoopptak 7B, 16.01.2009)

Scenen er et eksempel på hvordan studenten evner å lede undervisningen i samhandling med elevene i henhold til de kompetansemål det ble arbeidet med. Studenten og elevene viser evne til å samtale om hinduismen og til å knytte dette til ulike uttrykk fra kunst og musikk (K08, kompetansemål 5-7 trinn). Gjennom å studere scenen ses også samspillet mellom behov for spesifikk fagkunnskap og den valgte pedagogiske tilnærmingen. Scenen kan tolkes som at studenten forsøker å la elevene møte fagstoff i refleksive sammenhenger, hvor de får tolke det de møter egen forkunnskap og utvikle sin forståelse på egne premisser. Nøkkelscenen viser at det å delta i slike former for fortolkende samhandlinger fordrer at både lærer og elev får forberedt seg grundig slik at de evner å trekke ut relevant RLE-faglig innhold i stoffet de møter. Studenten tar elevenes perspektiv i forkant av sin andre gjennomføring, og på bakgrunn av sin nyervervede elevkunnskap fra 7A forbereder hun seg bedre faglig til timen. I tillegg viser både denne scenen og de foregående at også elevene trenger riktige rammebetingelser hvis målet er faglig deltakelse. Det er dette elevperspektivet artikkelen forfølger i den avrundende diskusjonen.

\section{Elevenes forutsetninger for faglig deltakelse}

Studentenes utprøving av den fortolkende kulturbevisste tilnærmingen påvirket på flere måter elevenes deltakelse og samhandling i undervisningen. Det første 
trekket jeg finner går igjen i scenene, og som har med elevenes vilje og evne til deltakelse å gjøre, er at den tiden elevene blir gitt til å forberede seg, er avgjørende. Ved å studere scenene i lys av faglig elevrespons, ser vi at der elevene viser motivasjon til å delta med egne fagkunnskaper og erfaringer, er de gitt tilstrekkelig med tid til å forberede seg. I den første nøkkelscenen ser vi at elvene blir gitt 8 minutter til å beskrive et kjent ritual, og at elevene i den andre scenen blir gitt 10 minutter til å foreta egne tolkninger av sammenhengen mellom en fortelling, et bilde av biskop Baasland og Bibelen. En av praksislærerne poengterer at han innledningsvis syntes studentene lot elevene arbeide vel lenge på egenhånd før de involverte dem i plenum igjen. Etter å ha fått se videoopptak av undervisningen oppdaget han imidlertid at elever som sjelden deltar i undervisningen hans, gjorde seg mer gjeldende når de fikk bedre tid enn normalt. ”Jeg satt bak i disse to timene og tenkte at jeg skulle ønske at ting gikk fortere. Men når jeg ser det her, ser jeg at de faktisk trengte denne tiden. Så nå tenker jeg at dette egentlig var veldig bra. [...] Det var faktisk mange som brukte tiden godt!” (Etterarbeidsmøte, 05.02.09). Funn som dette peker på at elever som ikke blir gitt tilstrekkelig med tid til individuell forberedelse, kan mangle forutsetninger for å delta i faglige dialoger, og dermed for å realisere viktige mål i skole og fag.

Et annet trekk som elevresponsen i nøkkelscenene avdekker, er at graden av faglig utfordring er av betydning. Bidragene fra elevene som tolket Ganeshmantraet i 7A, var ganske begrenset. Her ble de utfordret på bare ett nøkkelord og bedt om å fritt assosiere i en tegningsaktivitet. Først når oppgaven ble mer komplisert i 7B, ble tiden brukt godt til individuell faglig forberedelse som gav motivasjon til å delta i undervisningen med faglige bidrag. I nøkkelscenen om kontekstualisert fagkunnskap (pkt. 3 - pkt. 19) finner vi en dialog som ikke evner å bygge videre på tilgivelsesbegrepet satt på dagsorden. Det går tregt med elevenes skriving, og studenten forsøker å hjelpe til (pkt. 2) ved å gi dem flere stikkord. Min tolkning av nøkkelscenen er at elevenes mulighet til å bidra faglig, utilsiktet er begrenset ettersom utfordringen som er gitt i oppgaven er begrenset av studenten. Grunnene til at det ble slik, var at tilgivelsesbegrepet er fellesnevneren som all aktivitet i undervisningen vendte tilbake til, og at forståelsen av begrepet var ferdig tolket. Verken Erling i scenen eller Aatifa ble etter mitt skjønn gitt forutsetninger til å gi nye og andre relevante bidrag til dialogen ut over det å henvise til begrepet slik studenten hadde turnert det, og deltakelsen ble derfor sparsommelig.

En motsatt tendens kan vi finne ved å studere den første nøkkelscene. Her finner vi eksempler på elever som utfordres til å gi en utfyllende beskrivelse av de ritualer de selv har valgt. Videomaterialet viser at elevene bruker abstrakte stikkord skrevet på tavla (pkt. 6) og veksler mellom å kikke på tavla og ned på sine fortellinger. De utfordres til å bruke stikkord fra tavla for å gjøre sine individuelle tekster så gode og faglig relevante at de blir ivrige på å bidra med faglig innhold i undervisningen. Dette kan kalles for en type inkluderende 
undervisning som kan fremmes gjennom å utfordre elevenes "higher order thinking” (Lingard, 2007). Når Siri ivrig presenterer sin rike beskrivelse av Id, svarer hun i realiteten direkte på spørsmålene på tavla. Det er kompliserte utfordringer som er gitt, men samtidig eksemplifiserer nøkkelscenen at dette "trigger" elevene til grundig forberedelse og deretter utstrakt faglig deltakelse.

De tre nøkkelscenene legger på ulikt vis opp til at elever og lærer skal delta aktivt i undervisningen, og i så måte pågår undervisningen som samhandling (Wadel, 2005). Nøkkelscenene har vist en religionsundervisning forankret i elevenes egne interesser og livsverden. I første omgang betød det at elevene ble utfordret til å bidra inn i undervisningen med egne faglige forståelser. Innenfor ulik forberedelsestid har elevene forsøkt å gi seg forutsetninger til dette. Nøkkelscenene kan tolkes som at dette også handler om at de selv får være med å bestemme på hvilken måte de ønsker å delta faglig. En slik medbestemmelse svarer på sentrale målsetninger i RLE-faget som demokratiforståelse og medansvar, og et eksempel på dette i materialet var jeg inne på i kommentarene til den andre nøkkelscenen. Denne scenen ender med at begrepet tilgivelse forankres på ny i elevenes livsverden. Undervisningsforløpet avsluttes ved at elevene settes i gang med å dramatisere en fortelling knyttet til egne erfaringer med tilgivelse. Tom som i liten grad har deltatt så langt, og som av sine lærere beskrives som generelt lite deltakende, involverer seg aktivt og tar ansvar for oppgaven (Etterarbeidsmøte, 24.01.09). Tom viser seg som både en habil regissør og forteller, og som en god skuespiller. Dette er kompetanser han har tilegnet seg gjennom barneteateret. I scenen er han gitt anledning til å delta faglig i lys av egne interesser og kompetanser, og graden av deltakelse øker.

To andre eksempler på det å delta i RLE-dialoger på egne premisser gis i overgangen mellom pkt. 8 og pkt. 9 i nøkkelscenen om inkluderende vurdering. Her ber studenten ulike elever om å lese opp det de har skrevet om kjente ritualer. Turid blir bedt om å lese opp det hun har skrevet av sine medelever, ettersom de har merket seg at hun har skrevet veldig mye. Hun er først usikker, men velger på grunnlag av den ytre motivasjonen fra medelevene å lese. Medelevene sitter som "trollbundet" av fortellingen som både er velskrevet og tankevekkende, og medelevene applauderer henne etterpå (Videoopptak 7A, 03.02.2009). En situasjon som illustrerer noe av det samme, om enn med motsatt fortegn, er knyttet til eleven Balveer. Balveer er sikh og har skrevet om ritualet Holy. Ettersom Balveer i andre anledninger har bidratt med kunnskap om sikhisme, blir han bedt om å lese opp hva han har skrevet. Videomaterialet viser at han ikke har skrevet særlig mye, og han velger å takke nei til å lese. Studenten som leder undervisningen, gjør ikke noe nummer av dette. Dette eksempelet viser at inkludering i RLE-sammenheng ikke trenger å handle om at elevene eksplisitt bidrar inn i undervisningen. Tvert i mot vil det noen ganger være inkluderende å ikke avkreve at den enkelte skal måtte representere sin tilhørighet (mangel på tilhørighet) og dele sin tro (mangel på tro). 


\section{Avrunding}

I artikkelen har jeg forsøkt å vise hvordan utprøvingen av en valgt religionspedagogisk tilnærming tydeliggjorde behov for bestemt fagkunnskap i RLEundervisningen for både lærer og elev. Mine analyser av nøkkelscenene viser at studentdeltakerne i ROM-prosjektet ble utfordret i forhold til sin faglige forberedelse av undervisning, og at elevene ble utfordret med tanke på sin faglige deltakelse. Et eksempel på hva denne forberedelsen dreide seg om for studentene, var å bli kjent med elevenes interesser og egne problemstillinger i RLE-sammenheng. Mine tolkninger av nøkkelscenene viser at elevkunnskap om hva som oppfattes som interessant og relevant for den eksakte aldersgruppen og den enkelte elev, er viktig ved undervisning i tråd med en fortolkende kulturbevisst tilnærming. Samtidig er det i følge tilnærmingen viktig at læreren pendler undervisningen i retning av forståelser og spørsmål som også finnes utenfor elevens umiddelbare livsverden, til både en lokal tros- og livssynskontekst og til tradisjonene. Funn i nøkkelscenene indikerer at undervisning som følger dette prinsippet, krever ikke bare elevkunnskap, men fagkunnskap på ulike kontekstuelle nivå.

Nøkkelscenene viser videre at det å gi elevene tilstrekkelig med tid og tilpassede faglige utfordringer er betydningsfullt. Mine tolkninger av scenene fremhever dette som viktige faktorer for at elevene først skal kunne motiveres til grundig forberedelse, og deretter til å kunne delta i RLE-undervisningen på et faglig grunnlag. Analysene viser videre at lærere som leder slike fortolkende prosesser, selv må forberede seg faglig i forhold til elevenes potensielle fortolkninger av stoffet de presenteres for. En slik forberedelse vil gi RLE-læreren forutsetninger til å lede elevenes fortolkninger i retning av det kunnskapstilfanget som er iboende i de artefakter som anvendes i undervisningen, og de kompetansemål det arbeides med. Dette krever kunnskap om de forutsetninger elevene har til å gjøre egne tolkninger, og også grundig fagkunnskap om det bildet, musikkstykket, begrepet eller trossetningen som anvendes i undervisningen.

Mine analyser i artikkelen viser at utprøvingen av en fortolkende religionspedagogikk avdekket behov for denne typen religionsfaglig kunnskap i undervisningen. Om et slikt samspill mellom pedagogisk teori og behov for bestemt fagkunnskap vil gjelde ved bruk av andre pedagogiske tilnærminger og i annen fagundervisning, vil flere empiriske og fagdidaktiske forskningsprosjekter kunne være med å svare på. Det denne analysen fremhever, er at elevenes og lærernes deltakelse og samspill i RLE-undervisning basert på en fortolkende kulturbevisst tilnærming, er avhengig av at begge parter motiveres til grundig faglig forberedelse og til å bringe inn velfunderte faglige bidrag i de pågående fortolkningsprosessene. 


\section{Litteratur}

Alvesson, M. og Sköldberg, K. (2009). Reflexive Methodology - New Vistas for Qualitative Research. London: Sage.

Carr, W. and Kemmis, S. (1986). Becoming critical: Education, knowledge, and action research. London: Falmer Press.

Elliott, J. (1991). Action research for educational change Developing teachers and teaching. Milton Keynes: Open University Press.

Flornes, K. (2007). An action research approach to initial teacher in Norway, (PhD avhandling). Birmingham: The University of Birmingham.

Fossåskaret, E. (1997). Ustrukturerte intervju med få informanter, I E. Fossåskaret, O.L. Fuglestad og T. H. Aase. (red.) Metodisk feltarbeid - Produksjon og tolkning av kvalitative data. Oslo: Universitetsforlaget.

Fuglestad, O. L. (2007). Tett på praksis: Innføring i pedagogisk feltforskning. Bergen: Fagbokforlaget.

Fuglseth, K. (2006). “Horisontsammensmelting som metode”, I M. Brekke (red.) Å begripe teksten - om grep og begrep i tekstanalyse. Kristiansand: Høyskoleforlaget.

Geertz, C. (1973). The interpretation of cultures: selected essays. New York: Basic Books. Hammersley, M. og Atkinson, P (1996). Feltmetodikk. Oslo: Gyldendal

Jackson, R. (2009). The interpretive approach to Religious Education and the development of a Community of Practice, I J. Ipgrave, R. Jackson and K. O’Grady (Eds.) Religious Education Research through a Community of Practice: Action Research and the Interpretive Approach. Münster: Waxman.

Jackson, R. (2004). Rethinking religious education and plurality: Issues in diversity and pedagogy. London: Routledge \& Falmer.

Jackson, R. (1997). Religious education: An interpretive approach. London: Hodder \& Stoughton.

Kolb, D. (1984). Experiential learning: experience as the source of learning and development, Englewood Cliffs. N.J.: Prentice-Hall.

Kunnskapsdepartementet (2008). Kunnskapsløftet: fag og læreplaner i grunnskolen. Oslo: Pedlex norsk skole informasjon.

Lewin, K. (1946). Action research and minority problems. Journal of Social Issues, Vol. 2 (4), s. 34-46.

Lied, S. (2004). Elever og livstolkningspluralitet i KRL-faget: Mellomtrinnselever i møte med fortellinger fra ulike religioner og livssyn, (PhD avhandling). Elverum: Høgskolen i Hedmark.

Lingard, B. (2007). Pedagogies of indifference. International Journal of Inclusive Education Vol. 11, (3), s. 245-266.

Miles, M. B. \& Huberman, A. M. (1994). Qualitative Data Analysis. Thousand Oakes: Sage Publications.

Munthe, E. (2006). Visuell analyse: et mangfold av muligheter. I M. Brekke (red.) Å begripe teksten - om grep og begrep i tekstanalyse. Kristiansand: Høyskoleforlaget.

NOU (2007). Formål for framtida - Formål for barnehage og opplering. Kunnskapsdepartementet, Oslo.

Opplæringsloven (2008). Lov om grunnskulen og den vidaregåande opplæeringa. http://www.lovdata.no/all/tl-19980717-061-001.html

OSCE (2007). Toledo Guiding Principles on Teaching about Religions and beliefs in Public Schools. ODIHR.

Raab, J and Tänzler, D. (2009). “Video Hermeneutics”, I H. Knoblauch, B. Schnettler, J.Raab and H-G Soeffler (eds.) Videoanalysis : Methodology and Methods - Qualitative Audiovisual Data Analysis in Sociology. Frankfurth am Main: Peter Lang, s. 85-100. 
Skeie, G. (2010). Erfaringsbasert forsknings- og utviklingsarbeid, I G. Skeie (red.)

Religionsundervisning og mangfold - Rom for læering i religion, livssyn og etikk. Oslo: Universitetsforlaget, s.124-152.

Skeie, G. (1998). En kulturbevisst religionspedagogikk, (PhD avhandling). Trondheim: NTNU.

Von der Lippe, M. (2010). Youth, Religion and Diversity - A qualitative study of young people's talk about religion in a secular and plural society A Norwegian case, (PhD Thesis). Faculty of Arts and Education, Universitetet i Stavanger.

Wadel, C. (2005). Samhandling og relasjoner. Flekkefjord: Seek A/S.

Wenger, E. (1998). Communities of practice: Learning, meaning, and identity. Cambridge, Cambridge University Press.

Aase, T. H. og Fossåskaret, E. (2007) Skapte virkeligheter - Om produksjon og tolkning av kvalitative data. Oslo: Universitetsforlaget 